\section{Matematikk og medisin}

Aitken M, Broadhurst B, Hladky S. Mathematics for biological scientists

452 s, tab, ill. New York, NY: Garland Science, 2009, Pris GBP 32

ISBN 978-0-08153-4136-9

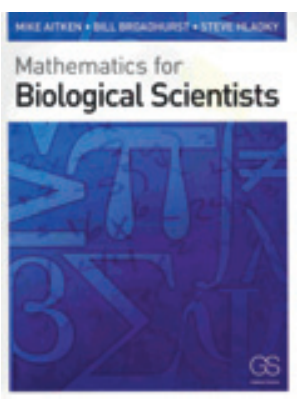

Matematikk er både et språk og et middel til resonnement - språk pluss logikk. Dette språket er uløselig knyttet til naturvitenskapelige fag som fysikk, men er også blitt stadig viktigere innen medisinen. Man

kan si at de store fremskritt i medisinen startet med at kvantitative metoder ble tatt i bruk, for eksempel ved at man stilte spørsmålet om aksepterte behandlingsmetoder virkelig var til nytte.

Denne utgivelsen har forskere i biologi som målgruppe, og det er interessant å observere at de fleste av de mange eksempler på anvendt matematikk som omtales er godt plantet i medisinen. Allerede i første kapittel behandles omregninger mellom enheter fra forskjellige systemer, som fra vekt/volum til molare løsninger. Bruk av vekt som mål for masse er fortsatt vanlig, slik at dette temaet blir praktisk og teoretisk av interesse for oss som kommer fra doktorskolene. Bl.a. blir vi i dette første kapitlet tatt med på å lage isotone infusjonsvæsker definert og beregnet ut fra primære prinsipper.

De 12 kapitlene har stort sett samme disposisjon. Matematikken som presenteres og tas i bruk, blir gradvis og (nesten) umerkelig mer komplisert etter hvert. Hvert kapittel begynner med et matematikkompendium, med løsning av likninger, utledninger av formler og bruk av grafer. Deretter følger brukseksempler fra det virkelige liv. Innsamlede kliniske data eller data fra forskningsprosjekter blir analysert og presentert trinn for trinn på en måte som kunne egne seg i en artikkel. Dette er et godt pedagogisk grep. Leseren blir så gitt oppgaver å løse.

Mathematics for biological scientists har en gjennomført konsistent layout med nyttige tabeller og fotografier. Sidene virker umiddelbart tiltrekkende, noe som kan motvirke eventuelle impulser til å gi opp underveis.

Kapitlene kan organiseres i fire temagrupper. Først kommer tallsystemer og algebra med vekt på konsepter som er relevante for biologiske kvantiteter, prosesser og strukturer. Man får etter hvert en samling regneverktøy til bruk når man ønsker å få fornuft ut av data fra den levende natur. Samlingen øker i neste temagruppe, som handler om matematikk som beskriver for- andring - differensial- og integralregning, med eksempler bl.a. fra endokrinologi, transport over cellemembraner og vekstdynamikk. Det har vært sagt at livet består i å bevege seg langs eksponentialkurver. Det kan bli svært galt å presse data inn i et diagram med lineær progresjon. Det tredje temaet er sannsynligheter og statistikk. De fleste sannsynligheter i biologien er med forbehold. For eksempel vil spredningen av influensa påvirkes av vaksinering og av hvor mange som fortløpende blir syke, med etterfølgende immunitet. Den siste temagruppen er statistikk, hypotesetesting og biologisk modellbygging. På dette feltet er det et stort tilbud av ferdige dataprogrammer som er «farlig» enkle å bruke. Disse programmene kan ikke alltid skjelne mellom forskjeller i betydning, målesikkerhet og fordeling av variabler. Noen variabler som burde ha vært med, kan man bare gjette seg til, mens irrelevante kan komme med (1). Resultatet kan ta seg fint ut, men behøver ikke bety noe. Som Richard Feynman sa: «Think first - compute later.»

Slike problemer har forfatterne her styrt unna. Alle matematiske uttrykk er utledet. Det er lagt opp til selvstudium av denne boken. Leger vil sannsynligvis her finne tilstrekkelig uttømmende svar på spørsmål som omfatter bruk av matematikk i medisinfaget. Jeg tror også mange lesere vil få nye ideer til datapresentasjon og dataanalyse.

\section{Anton Hauge}

Avdeling for fysiologi

Universitetet i Oslo

\section{Litteratur \\ 1. May RM. Uses and abuses of mathematics in biology. Science 2004; 303: 790-3.}

\section{Kort om målrettet klinisk undersøkelse}

Talley NJ, O'Connor S.

Pocket clinical examination

3. utg. 238 s, tab, ill. Jacksonville, FL: Churchill Livingstone Elsevier, 2009. Pris USD 55

ISBN 978-0-7295-3872-5

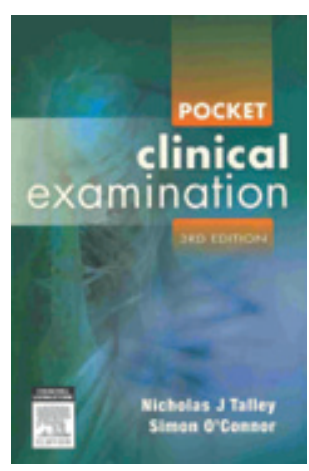

Denne utgivelsen er beregnet på medisinstudenter som skal lære seg å beherske det viktigste redskapet «i kofferten»- anamneseopptaket og den kliniske undersøkelsen. Den er en følgesvenn til storebror Clinical examination: a

systematic guide to physical diagnosis. Kortversjonen har et hendig format og tynger ikke mye i en frakkelomme. Den bygger opp under «objective structured clinical examinations» (OSCE), det vi i Norge kaller stasjonseksamen. Alle kapitlene har eksempler på slik målrettet undersøkelse. Under «akutt sykdom»: Pasienten har vært bevisstløs, undersøk ham. Hvoretter det i åtte punkter legges en plan for å gjøre dette målrettet.

De første kapitlene er Taking the history og Advanced history taking. Deretter kommer undersøkelsesteknikk for organsystemer, så mot slutten geriatrisk pasient og akutt syk pasient, før det hele rundes av med hvordan man skriver og presenterer sykehistorie og funn. Ifølge det som er tradisjon i mange andre land, trekkes her den aktuelle sykehistorien (logisk nok?) frem først. For øvrig er ikke klinisk arbeid vesensforskjellig over landegrensene, og Pocket clinical examination er spekket med gode råd og tips om hvordan man gjennomfører en målrettet anamnese og undersøkelse. Det er et rikelig antall tegninger. De er enkle og illustrative, men mangler det artistiske som av og til gjør at man savner Netter.

Det finnes mange alternative utgivelser, og erfaringsmessig velger også en del studenter å støtte seg på hefter og stensiler som deles ut i propedeutterminen. Jeg tror imidlertid mange vil kunne ha glede av denne boken når grunnlaget skal legges for et langt arbeidsliv.

Alle kapitlene innledes med mer og mindre treffende sitater. Det kan kanskje passe å hitsette ett som en spore for flere av oss til å opprettholde bred klinisk interesse, kunnskap og uopphørlig lærevilje - «Specialist - man who knows more and more about less and less» (Wilhelm James Mayo, 1861-1934).

\section{Olav Sandstad}

Gastromedisinsk avdeling Oslo universitetssykehus, Ullevål 